\title{
Causes and Countermeasures of P2P Mine Explosion in China
}

\author{
Yinge Xiong1, a, Ping Qin ${ }^{1}$ \\ ${ }^{1}$ College of management, Sichuan University of Science \& Engineering, Sichuan City, 644000, China \\ a1939831765@qq.com
}

\begin{abstract}
This paper analyzes and discusses the phenomenon of P2P mine explosion, and explores the reasons and factors behind it, and puts forward corresponding countermeasures against the background of the development of $\mathrm{P} 2 \mathrm{P}$ project, from no one's interest in market innovation to the barbaric growth to the establishment of more than 3000 institutions in only three years, which has become the bleak end of institutional bankruptcy and platform running.
\end{abstract}

Keywords: P2P mine explosion; Reason; Countermeasure.

\section{P2P Project Explosion}

\subsection{Overview of $P 2 P$ Project}

The full name of P2P is "peer-to-peer", corresponding to "peer-to-peer" in Chinese. The P2P model is that the lender gets interest, the borrower gets funds, and the platform earns a commission in the middle. As borrowing money from banks requires a lot of procedures, such as data approval, property mortgage, etc., there is a certain threshold for banks to borrow money. With P2P, people with loan needs publish loan information on the platform, such as how much money to borrow, how long to borrow, interest rate and so on. The platform collates the borrower's information, determines the risk level according to his credit analysis, and matches it to the lender. If you have spare funds, you can lend money to others on the platform and charge a certain interest at the same time. P2P net loan plays the role of an information intermediary and earns a management fee. Therefore, because of its easy borrowing conditions and convenient handling, it not only reduces the difficulty of financing for small and micro enterprises and individuals, but also brings a lot of interest to borrowers such as investors.

P2P projects originally came from the UK, once prevailed in the United States, developed rapidly in China, and brought great risks. Since the development of the project, the huge returns brought by $\mathrm{P} 2 \mathrm{P}$ project have made many people earn a lot of money, so that the news of thunder and running on the $\mathrm{P} 2 \mathrm{P}$ platform in the later stage continues to be reported, and the expansion speed of $\mathrm{P} 2 \mathrm{P}$ project is still surprising. According to statistics, the historical cumulative turnover of the domestic P2P online loan industry hit trillion yuan for the first time in 2015. By June 2019, the historical cumulative turnover of $\mathrm{P} 2 \mathrm{P}$ online loan had exceeded 7 trillion yuan.

\section{2. "Thunder Burst" in P2P Projects}

In 2012, the Internet plus mode swept across all sectors, and the Internet plus financial $=\mathrm{P} 2 \mathrm{P}$ became the trend of the times. In 2014, a wave of mass innovation was launched. Driven by the background of financial liberalization and the development of information technology, the Internet financial industry represented by P2P online lending and other lending platforms developed rapidly. By 2015, the number of P2P platforms had increased rapidly from the initial 10 to 3595 .
From 2015 to 2017, it was the highlight moment of P2P, and the platforms developed into more than 5000. The outbreak of P2P industry has opened the door to wealth and attracted funds from banks, listed companies and private enterprises.

However, although P2P online lending has played a positive leading role in financial innovation, this innovation has not reduced the risks existing in the financial industry, but has become more harmful to the society. In December 2015, "e-rent treasure" exploded, followed by "investment house" in July 2018. With the emergence of the "thunder wave" of P2P industry, citizens involved in it have suffered huge losses. According to incomplete statistics, only from May to July 2018, when the "thunder burst" was the most serious, there were 327 platforms with problems such as closure, running away and cash withdrawal difficulties in China, and the scale of problem $\mathrm{P} 2 \mathrm{P}$ online lending institutions involved has exceeded RMB 800 billion .

The "explosion of thunder" not only rapidly cooled the booming P2P, but also made investors completely lose heart in P2P. From nearly 6000 platforms in the original peak period to August 2020, there are only 15 P2P platforms left.

\section{Problems in P2P Projects}

\subsection{P2P Online Loan Is Contrary to Business Ethics}

In the P2P online loan industry, the lack of ethics is also very common. For example, the actual controllers of some P2P institutions are dishonest Executees, who use the regulatory gap to fictitious loan projects on the Internet or register shell companies to raise funds and squander them wantonly; Some P2P institutions do not disclose risk information and "lure" lenders to invest with high profits by means of a large number of red envelopes, interest rate increase bonds, lending and cash back; Some P2P borrowers defraud loans in multiple P2P institutions and form an "anti collection alliance" to maliciously attack P2P institutions in order to evade debts, etc.

On the one hand, there are about 20 domestic P2P platforms listed overseas, which can prove that the financial innovation in business model is successful at least; However, if we observe it from the perspective of ethics, we will draw the opposite conclusion. P2P itself is nothing new. It is similar to the subprime mortgage in the United States. It is only that P2P 
realizes viral rapid sales through the Internet, which does not have much investment value. Lending money to people who are unable to repay is in itself contrary to business ethics. Foreign small bar owners know that they will never sell the last cup of wine to people who are drunk and unable to walk in order to earn money for the last cup of wine. The cornerstone of the stability of the financial industry is the spirit of contract, and Internet finance can not solve this business ethics problem at least at present. In the market, those successful P2P platforms either operate consumer loans and auto loans, or operate credit card installment, campus loans, etc. Taking borrowers and students who know little about credit loans, have low credit limit and lack repayment ability as the main market targets, through continuous language misleading or word fraud, these borrowers are encouraged to "over consume" and "over debt", which also shows the "evil" side of human nature and "stimulate evil with evil", resulting in overdue non repayment in the market Borrow the new and return the old.

Lending is not a physical transaction such as buying and selling houses. The credit investigation system and the credit investigation ability and cost of ordinary lenders do not support their credit evaluation of borrowers. Especially on the illusory network, they need professional institutions to provide credit enhancement services. If the platform is not allowed to provide guarantee, the moral hazard of the platform due to lax audit or joint borrower loan fraud is inevitable. When the platform has the ability to reveal the bottom, the platform will vaguely publicize that it can provide implicit principal and interest guarantee. Once it loses the ability to advance, it will use the law to avoid its responsibilities.

\subsection{The Regulatory System Is Not Standardized}

At beginning of the development of the P2P industry in China in 2012, such platforms were almost unsupervised, and corresponding laws and regulations were not established. This will only cause the financial supervision department to fail to perform its supervision responsibilities and the division of labor within the Department can not be implemented in place. Moreover, due to the non-standard platform system, many online loan platforms lend in violation of regulations, and have established a capital pool through self financing mode and self guarantee mode. Once there is such an unregulated capital pool, it is easy to have accidents. The platform side is easier to roll money and run away, and the capital pool is also the best way to cover up the "Ponzi scheme" to borrow new and return the old. In front of the huge profits of P2P, people want to get rich overnight, but forget that the risks and benefits are the same. Since November 2016, China has successively issued documents such as guidelines for filing and registration management, three reductions of online lending institutions, and punishment of usury.

P2P institutions sell loan products under the name of high return. Under the inducement of high interest, the masses have taken the bait and poured into a large number of investors with low risk awareness. According to the statistics of online loan home, P2P investors are mainly working-class, accounting for about $58 \%$; More than $80 \%$ of investors have a monthly income of less than 10000 yuan. Most of the two users who have reached a loan relationship are investors who are accustomed to rigid cashing, while the lender is a borrower who lacks the ability to repay. This unbalanced structure leads to an unusually high bad debt rate of the project. Whenever there is a capital problem on the $\mathrm{P} 2 \mathrm{P}$ platform, it is easy to cause a large area of extensive disputes and rights protection, This has led to social instability to a certain extent.

At the same time, because the system of the domestic credit investigation system is not perfect, if the borrower has overdue debts or malicious debt evasion, it cannot be directly incorporated into the national credit investigation system, and the P2P platform has great difficulty in risk control and high actual operation cost, so it is difficult to promote the sustainable development of the business model.

\subsection{Imperfect Information System}

Because the $\mathrm{P} 2 \mathrm{P}$ platform is not rigorous enough in user information audit, there are a large number of people who are unable to repay and do not have borrowing qualifications who can borrow. Moreover, the P2P platform also has certain risks in user information screening and identification. If the personal data submitted by the borrower is fake and concealed, and the platform does not identify it, this situation may also exist. Therefore, it is easy to be maliciously exploited when screening users, which makes it more difficult for the platform to calculate the user's real credit.

In addition, some $\mathrm{P} 2 \mathrm{P}$ platforms deliberately conceal their own information, such as publishing some false investment projects, fabricating virtual borrower information to induce investors to invest, or concealing and fabricating the whereabouts of funds for real projects, falsely reporting the bad debt rate and overdue rate on the project details page, or directly erasing this item, and exaggerating the yield of the project, Charge for other items or deduct fees secretly without notifying investors.

\section{Countermeasures}

\subsection{Improve the Supervision System}

\subsubsection{Improve the Regulatory Framework and System}

Legally, we should clarify the positioning of P2P platform in online lending, clarify responsibilities and norms of conduct, which not only provides a strong basis for the future development of P2P, but also makes criminals have no loopholes to drill. In the overall system construction, we should not only give full consideration to the macro level, but also consider the micro aspects. At the same time, we should also consider the "black swan" of emergencies at extreme moments, improve the professional level and risk control ability of various institutions, and form a perfect, comprehensive and sustainable regulatory framework and system.

\subsubsection{Build A Regulatory Mechanism to Guide Market Innovation}

The pace of financial market innovation will always be ahead of the pace of supervision. Simply suppressing financial market innovation is not a long-term way, but we can limit the impact on financial market innovation to a reasonable range and strengthen the interaction between government regulators and market environment by exploring the continuous test of innovation in supervision, "regulatory sandbox" and other management modes, So as to jointly promote the innovation and orderly development of the financial market in a good direction.

When the pace of supervision and innovation cannot be consistent, the industry should take a cautious attitude 
towards the innovation of the financial market, especially resolutely eliminate the illegal acts that infringe on interests or disrupt the market, clean up and standardize them in time, guide the internalization, explicit and standardized development of "financial pseudo innovation" (such as ICO, currency speculation, etc.), and strengthen scientific and technological governance. At the same time, regulators should arm themselves through digital, scientific and technological means, vigorously develop monitoring technology, improve risk foresight, sensitivity and accuracy, and realize measurable and controllable risk.

\subsection{The Financial Industry Should Adhere to the Concept of Responsible Innovation and Actively Accept Supervision}

The financial industry needs to have the concept of financial innovation, which should meet the specific needs of market participants, but it will also bring challenges to the regulatory authorities or the public, and there will be uncontrollable risks. Therefore, we should rationally view the necessity and role of supervision, actively accept and embrace supervision while innovating, and vigorously develop compliance technology; Closely combine financial innovation with understanding your customers, products and businesses, embed regulatory requirements into business processes, grasp moderation, improve transparency, reduce complexity and control spillover. At the same time, the industry should strengthen the ethical and spiritual construction of employees, adhere to the principles of balance, responsibility and sustainability, and launch more highquality innovations to meet the sustainable development of society and the real needs of the real economy on the basis of full demonstration of risks, so as to lead economic development and social progress with financial innovation.

\subsection{Strengthen Investor Education}

Investor risk education is an indispensable process for risk prevention. It is a long-term and systematic project. It is also one of the most long-term methods in the financial risk prevention and control mechanism. In terms of how to strengthen it, on the one hand, various regulatory departments and government associations in the industry should closely cooperate and work together to make scientific planning in different periods, do a good job in special promotion through the combination of online and offline, and implement it into daily actions, so as to promote the implementation of financial knowledge and risk education to thousands of households and spread to the classroom, Realize the overall improvement of residents' financial literacy and financial knowledge reserve. On the other hand, from the perspective of financial institutions, by strengthening regulatory measures and adding incentive regulations, financial institutions and financial practitioners can enhance their awareness of protecting the rights and interests of financial consumers, and increase appropriate management for investors, so as to prevent false and exaggerated publicity such as "talking about the benefits and passing the risks" and adhere to "Sell the right products to the right people in the right way" to achieve an appropriate balance between consumer management and business development.

Both the financial regulatory system and the innovation of the financial market have shown a specific periodicity, with one ebbing and the other ebbing. Like the financial market and the market economy, regulators and the industry must take the initiative to balance development, innovation and stability, so as to achieve a dynamic balance between the three. Development is the primary task and eternal theme, and innovation is the key to promoting development Means, to achieve sustainable development, we should not only maintain the stability at the static level, but also maintain the dynamic level, so as to promote the better and more stable sustainable development of China's economy.

\section{References}

[1] What does P2P bring us? He Jie. Tsinghua financial review. 2020.

[2] Financial technology, optimal banking market structure and credit supply of small and micro enterprises. Sheng Tianxiang, fan Cong. financial research. 2020.

[3] Development, problems and supervision of China's P2P network lending industry [J]. Feng Xingyuan, Yan Xiang, Cheng Ping. Social science front. 2020 (09).

[4] Zhang Maojun, Wang Jian, Zhang Yin, Zhang Yedan. Financial technology, regulatory policy and P2P platform risk -- from the perspective of credit risk and liquidity risk [J]. Finance and economy, 2021 (08): 38-45.

[5] Weakness, breakthrough and system construction of China's financial technology supervision. Wang umbrella. Monthly journal of Finance and accounting. 2021. 